\title{
51. MIDDLE MIOCENE SALINITY CRISIS AND PALEOGEOGRAPHY OF THE PARATETHYS (MIDDLE AND EASTERN EUROPE)
}

\author{
F. Rögl, Geologisch-Palaeontologische Abteilung Naturhistorisches Museum Wien, Vienna, Austria \\ F. F. Steininger, Paleontological Institute University Vienna, Vienna, Austria \\ and \\ C. Müller, Geologisch-Paleontologisches Institut Senckenberg-Anlage, Frankfurt/Main, West Germany
}

\begin{abstract}
Miocene plate tectonic activity created regions of relatively restricted marine sedimentation-the Mediterranean and the Paratethys Seas-which evolved from the Tethyan Ocean. These resulting configurations brought about periodic faunal exchanges between central Europe, the marine realms of the Indo-Pacific and the terrestial realms of Africa. Rapid change in marine depositional environments occurred during the middle Miocene in the Paratethys Sea. After a peak in marine sedimentation during the early Badenian, there was a widespread desiccation in the late middle Badenian in the Carpathian foredeep and eastern intramontaine basins. This "salinity crisis" was caused by the closing of the marine seaway to the Indo-Pacific and gave rise to the brackish water "Spaniodon" beds of the Karaganian Stage of the eastern Paratethys Sea.

Late Badenian floral and faunal assemblages indicate that the seaway to the Indo-Pacific was reopened and the Paratethys area again flooded, whereas the seaway to the Mediterranean had disappeared. Finally, within the late Miocene and Pliocene the Paratethys area was isolated from any marine influence and has become progressively more fresh since that time.
\end{abstract}

\section{INTRODUCTION}

Application of the concepts of plate tectonics to the Alpine System demonstrates that during the Tertiary a change in relative African-European plate motions occurred during which earlier counterclockwise rotation and trascurrent motion became mainly convergent motion (Dewey et al., 1973; Hsü, 1971; McKenzie, 1970; Neev, 1975). This collision broke up the Tethys oceanic realm which had existed since the early Mesozoic and resulted in the (T 9-Tethys phase of Dewey et al., 1973) formation of several relatively small basins and troughs during the Neogene. These basins and troughs are the Mediterranean and Paratethys seas, the Mesopotamian Basin, and the oceanic trough which stretches towards the Indo-Pacific Ocean. Continuing compressional forces from the Oligocene onward, markedly increased subduction, transform faulting, and thrusting developed several sedimentary regions within the Central Paratethys: the AlpineCarpathian foredeep and a number of intramontaine basins (Senes et al., 1971). The evolution of progressively differentiated faunal assemblages within these Neogene seas resulted in the development of regional stage concepts for the Mediterranean, and the central and eastern Paratethys (Figures 1 and 2).

Investigations of nannoplankton and foraminifera of DSDP Leg 42A revealed major differences in the middle Miocene faunal assemblages between the Paratethys and the Mediterranean seas and raised questions which led to the following study.

\section{EARLY MIOCENE SEAWAYS}

Early and middle Oligocene faunal assemblages are more or less uniform throughout Europe. The beginning of faunal differentiation began in the late Oligocene in the northern and western Mediterranean and Paratethyan-faunal realms.

The early Miocene of the Paratethys area (Eggenburgian/Sakaraulian and Ottnangian/Kozachurian) is characterized by uniform, widespread faunal renewal. The fauna includes a most distinctive and diverse molluscan fauna, which includes numerous "giant" taxa as a result of exlosive evolution and migration during that time (Steininger et al., 1975). This fauna indicates a connection existed with the Indo-Pacific Ocean and its deposition is generally concurrent with a worldwide transgressive phase, probably related to an accelerated spreading rate in the early Miocene. The seaway can easily be traced from the Persian Gulf and western Iran, including the Quom Basin, across Iraq and the Mesopotamian trough to eastern Turkey and across southern Russia (Crimea area) into the Paratethys. Moreover, it can be traced across the Mesopotamian Basin and northwest Syria into the 


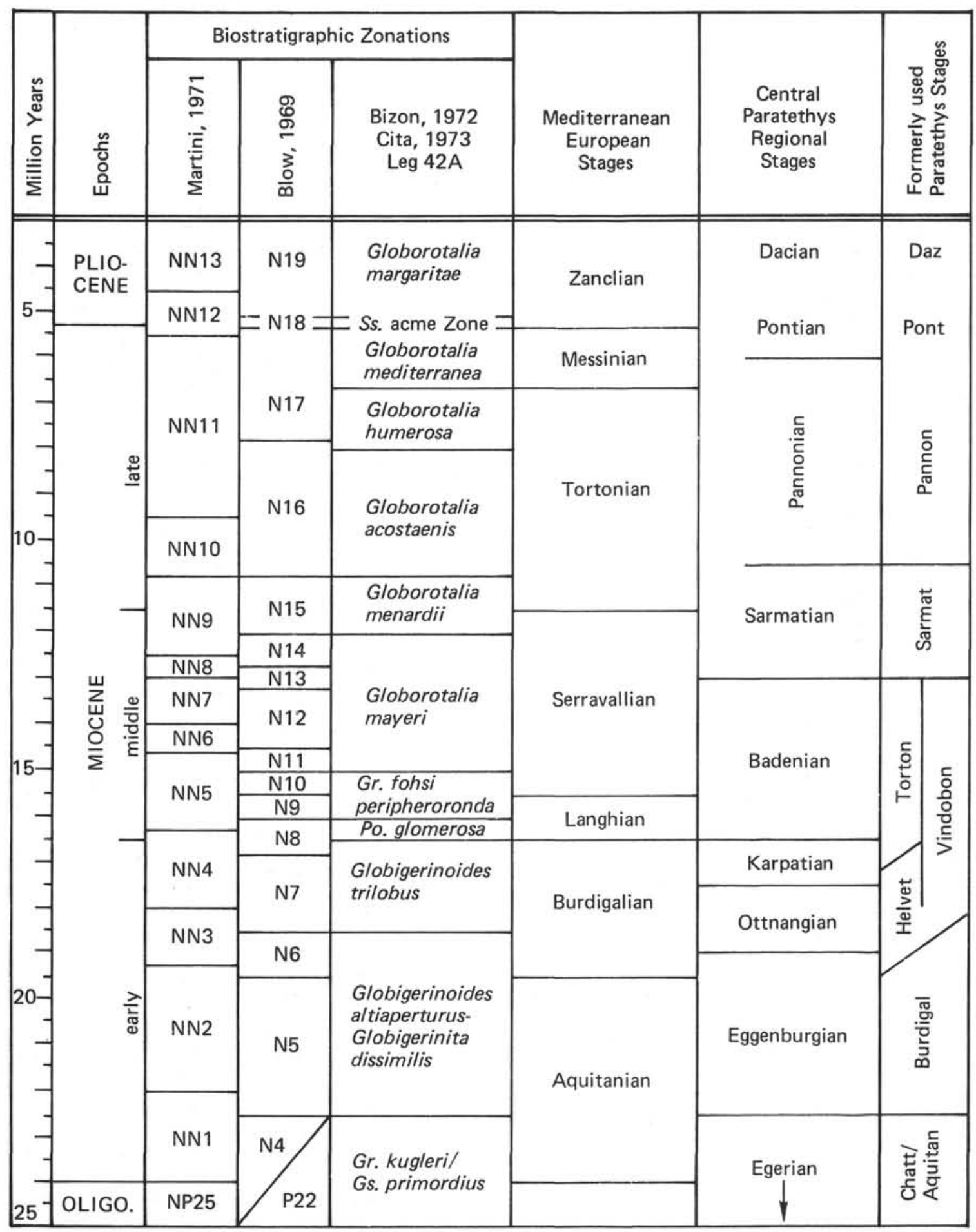

Figure 1. Neogene biostratigraphy and tentative correlation of central paratethys stage concept.

Levantine Sea (eastern Mediterranean), on the basis of a transgressive phase into the Red Sea rift zone.

The existence of this oceanic strait from the IndoPacific to the Paratethys and the Mediterranean seas is consistent with the configurations resulting from plate tectonics in this area (Dewey et al., 1973, p. 3169, fig. 18; Hsü, 1971 and personal communication). By late Eggenburgian/early Ottnangian time this marine sea- way extended further west and connected the western Alpine foredeep across Bavaria, Switzerland, and the Rhone Valley to the western Mediterranean Sea. A regional late Ottnangian/Kozachurian regressive phase is characterized by the "Rzehakia" mollusk assemblage, which was deposited from Bavaria to the eastern Paratethys. This regressive phase ended the first marine Miocene cycle within the Paratethys. 


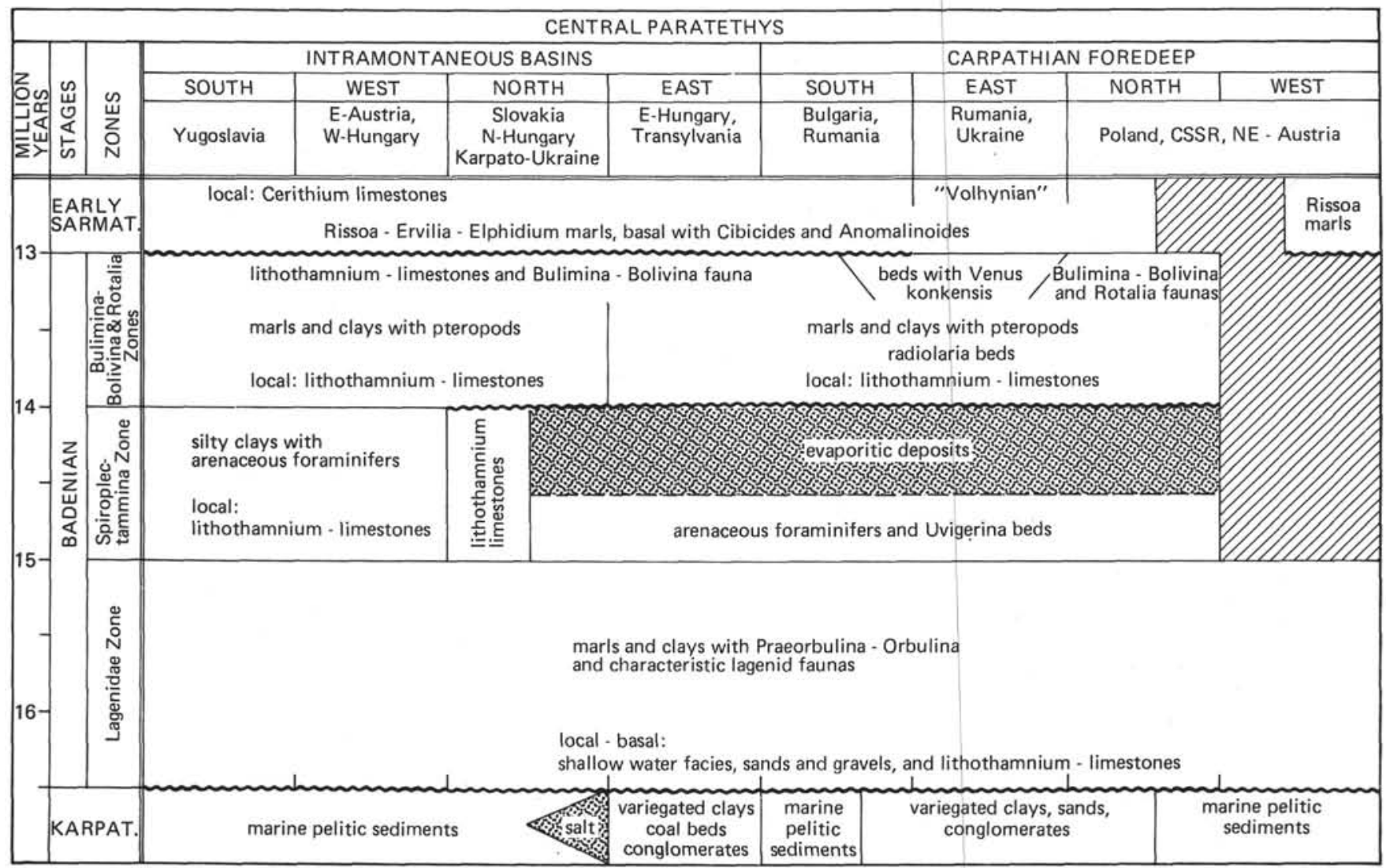

Figure 2. Middle Miocene sedimentary sequences of the central Paratethys regions (simplified according to Cicha et al., 1975).

\section{THE MIDDLE MIOCENE SALINITY CRISIS}

\section{The Karpatian Transgression, 17.5-16.5 m.y.B.P. (Figure 4)}

Throughout the entire central Paratethys, in addition to the central Pannonian Basin, the Karpatian stage is marked by a pronounced transgressive phase and a mollusk fauna of Mediterranean affinities. Within the central Pannonian Basin marine sedimentation seems to be continuous from the Ottnangian to the Karpatian stages. The pectinid fauna of this area is closely related to the western Mediterranean/Atlantic fauna (Kokay, 1967, 1973, loc. 1). The facies development of the Lom Basin (loc. 2) also suggests an open marine seaway existed toward the Indo-Pacific Ocean.

Variegated clays, sands, conglomerates, and coal beds which lack marine fossils (see Figure 3) occur throughout the entire Carpathian foredeep from southeast Poland (loc. 3) to Rumania (loc. 4) and within the intramountaine basins in Transsylvania (loc. 5) and the Carpatho-Ukraine (loc. 6). This confirms our view that marine equivalents to the Karpatian stage are missing in the entire eastern Paratethys. Marine sediments are also missing throughout the entire western Alpine foredeep from the southern rim of the Bohemian Massive (loc. 7) westward.

The distribution of the Karpatian-Badenian marine sediments (Figures 4 and 5) justifies the restriction of the stratigraphic position of the Devinska Nova Ves (situated at the river March fissure mammal fauna [loc. 8]) to the Karpatian (Cicha et al., 1972; Steininger et al., 1975) stage.

\section{The Badenian Marine Peak, 16.5-14.5 m.y.B.P. (Figure 5)}

A far-reaching transgression coming from the IndoPacific characterizes the Badenian marine peak. Even within tbe areas of deposition of the Karpatian, for example, northern Yugoslavia (loc. 1), the Styrian Basin (loc. 2) and Pannonian Basin (loc. 3), and the western Carpathian foredeep (loc. 4), we recognize a distinct unconformity (see also Figure 3 ) between the Karpatian and Badenian stages. This transgression reaches to the Transsylvanian Basin (loc. 5) and flooded the entire Carpathian foredeep from Austria to Rumania (loc. 6). The marine environment spread out of the Carpathian foredeep far east across the Russian platform, and is represented by the Tarkhanian facies with an endemic fauna best characterized by the mollusks (Nevesskaya et al., 1975a).

From there one branch reached across eastern Anatolia into the Paratethys (loc. 7) and another splitting from the Mesopotamian trough reaching across northwestern Syria and the Taurid area into the Mediterranean (Bering, 1971; Becker-Platen, 1971; Lange, 1971; 


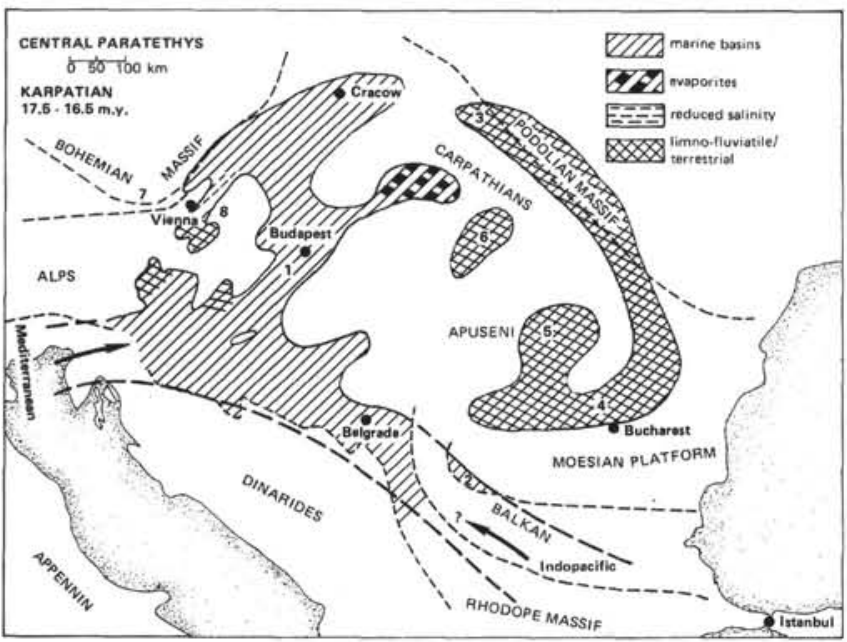

Figures 3 to 6. Middle Miocene paleogeographic concept, facies distribution and proposed marine connections of central Paratethys (loc. 1, 2, $3=$ localities and areas referred to in text).

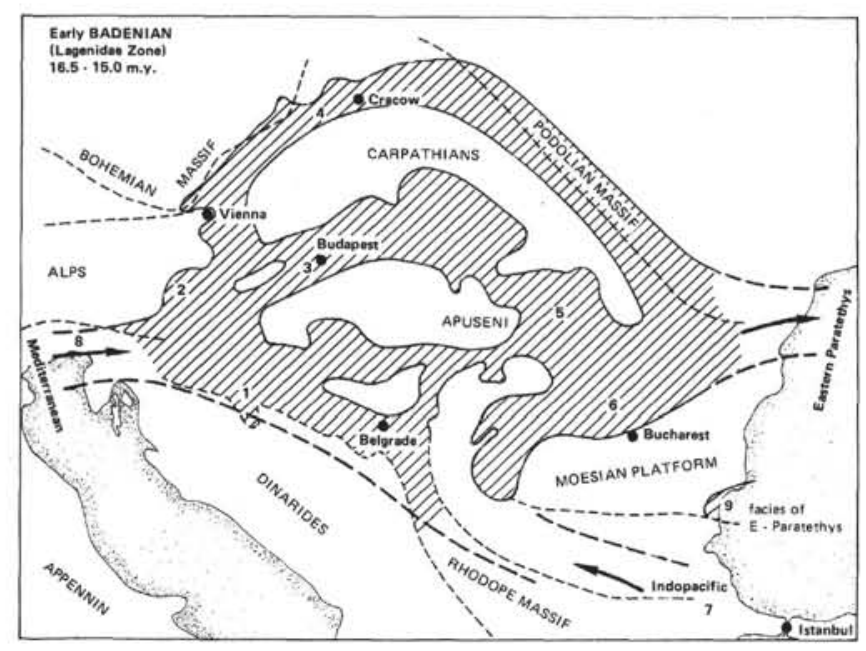

Figure 4.

Lüttig and Steffens, 1976; Sickenberg, 1975). This seaway existed from the late Oligocene until the middle Miocene ( 25 to 14 m.y.B.P.).

The other active seaway which extended from the southwestern central Paratethys (loc. 8) toward the Mediterranean into the northern Italian region of Langhian-Serravallian deposition must still have been in existence, as indicated by the presence of AtlanticMediterranean deep water ostracodes (Jiřiček, 1974) and sedimentary relicts of the Tarkhanian facies in Carinthia and northern Yugoslavia (Daniels and Ritzkowski, 1970).

The relicts of the Tarkhanian facies in the Varnagulf (loc. 9) demonstrate that the areas of the eastern Moesian platform, the Black Sea, and northern Anatolia (Brinkmann, 1976) were already separated from Indo-Pacific northward compressional plate movements (Hsü, 1971 and personal communications). These compressional plate movements of the African and Arabian plates against the Iranian, Van, Turkish,

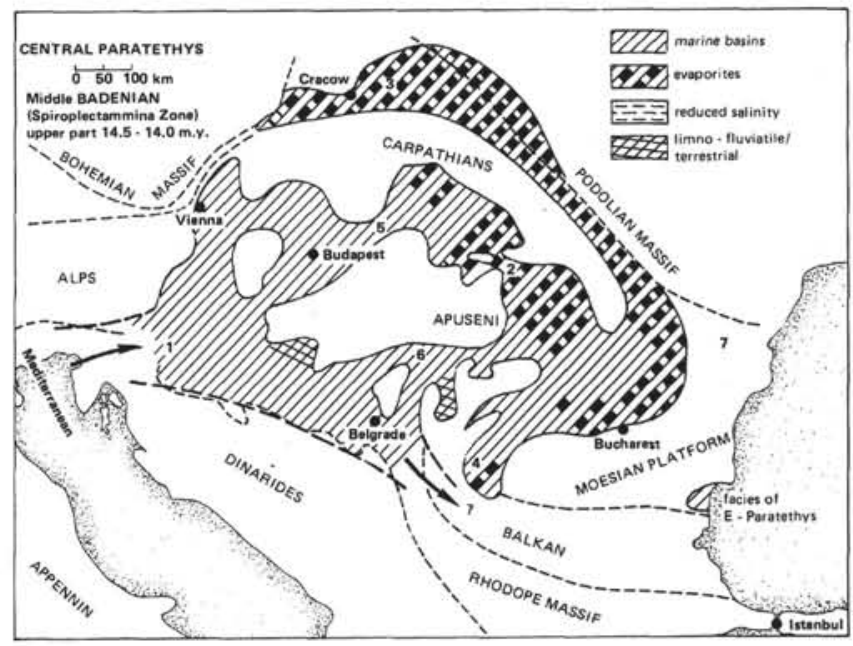

Figure 5 .

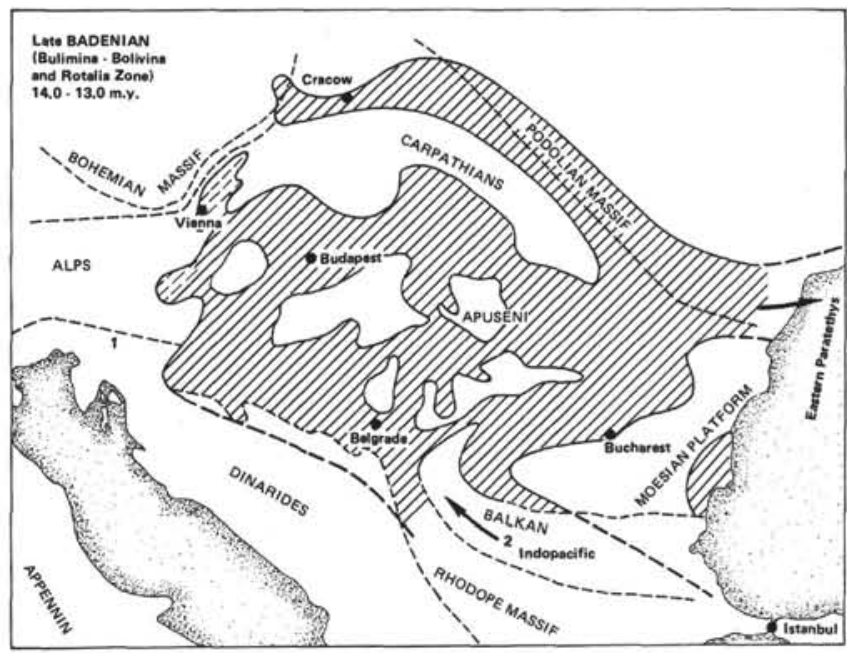

Figure 6.

and Aegean plates which in turn pressed against the Caspian, Moesian, and Eurasian plates, squeezed the Turkish and Moesian plates westward, which closed and buried in the late Neogene, this middle Miocene ocean strait beneath the resulting Pontian-Balkanian mountain chain (Dewey et al., 1973; Herz and Savu, 1974; McKenzie, 1970; Neev, 1975).

\section{The Badenian Desiccation, 14.5-14 m.y.B.P. (Figure 6)}

The elevation and emergence of the African and Arabian plates resulted in complete separation of the Mediterranean Sea from the Indo-Pacific at about 14 m.y.B.P. (Buchbinder and Gvirtzman, 1976). The northward movement of plates narrowed the Mesopotamian trough and almost sealed off the ocean connection towards the Paratethys. The only middle Badenian marine connection still existing stretched from the southwestern central Paratethys (loc. 1) to the Serravallian sedimentation in the western and southwestern parts of the central Paratethys intramountaine basins (Figure 3). Rich faunas with Globoquadrina dominate 
both the planktonic and benthic faunas, and mollusk species continue to show Mediterranean affinities. The eastern parts of the intramountaine basins from Slovakia to Transsylvania (loc. 2) and the Carpathian foredeep from Poland (loc. 3) to Rumania and Bulgaria (loc. 4) became evaporitic. The marine connection of these evaporite basins occur within northeastern (loc. 5) and southern Hungarian sill areas (loc. 6) marked by a Lithothamnium-limestone facies (Figure 2).

A corresponding desiccation phase with a number of short marine transgressions came into existence at the same time in the Mesopotamian trough (Buchbinder and Gvirtzman, 1976). The eastern Paratethys contain a marine fauna in the Tarkhanian and the Tshokrakian stages corresponding to the lower parts of the middle Badenian (Figure 2). Isolation from the Indo-Pacific and an emergence of the Dobrodga (loc. 7) resulted in the dimunition of marine conditions and gave rise to the widespread deposition of the brackish water "Spanidion" beds of the Karaganian stage (Nevesskaya et al., 1975b).

\section{The Late Badenian Marine Flooding, 14-13 m.y.B.P.} (Figure 7)

A far-reaching transgression flooded the entire area of the central and eastern Paratethys in late Badenian time and covered the evaporitic sequences with radiolarian and pteropod marls (Figure 2). This facies, as well as the fauna of the late Badenian, correlates with the Konkian stage of the eastern Paratethys. The planktonic forms became more abundant southeastward of the investigated area. Planktonic foraminiferal fauna, with Globigerina druryi and $G$. decoraperta, indicate a stratigraphic position within Blow's Zone N.13, and is characterized by the development of the genus Velapertina, so far known only from the Paratethys area. Another genus specific to Paratethys is the

\begin{tabular}{|c|c|c|c|c|c|}
\hline $\begin{array}{l}\text { MEDITERRANEAN } \\
\text { REGION }\end{array}$ & \multicolumn{2}{|c|}{$\begin{array}{l}\text { CENTRAL } \\
\text { PARATETHYS }\end{array}$} & \multicolumn{3}{|c|}{$\begin{array}{c}\text { EASTERN } \\
\text { PARATETHYS }\end{array}$} \\
\hline \multirow{4}{*}{ Tortonian } & \multirow{3}{*}{\multicolumn{2}{|c|}{ Pannonian }} & \multicolumn{3}{|c|}{ Maeotian. } \\
\hline & & & & Chersonian & \\
\hline & & & late & Rescarahian & 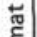 \\
\hline & \multirow{2}{*}{\multicolumn{2}{|c|}{ Sarmatian }} & early & Dessarabian & \\
\hline \multirow{3}{*}{ Serravallian } & & & & Volhynlan & \\
\hline & \multirow{3}{*}{ Badenian } & late & & Konkian & \\
\hline & & middle & \multicolumn{3}{|c|}{ Karaganian } \\
\hline Langhian & & early & \multicolumn{3}{|c|}{$\begin{array}{l}\text { Tshokrakian } \\
\text { Tarkhanian }\end{array}$} \\
\hline \multirow{3}{*}{ Burdigalian } & \multicolumn{2}{|c|}{ Karpatian } & \multicolumn{3}{|c|}{ DIDIDIIIIII } \\
\hline & \multicolumn{2}{|c|}{ Ottnangian } & \multicolumn{3}{|c|}{ Kozachurian } \\
\hline & \multicolumn{2}{|c|}{ Eggenburgian } & \multicolumn{3}{|c|}{ Sakaraulian } \\
\hline Aquitanian & \multicolumn{2}{|c|}{ Egerian } & & Caucasian & \\
\hline
\end{tabular}

Figure 7. Tentative correlation of Mediterranean, central, and eastern Paratethys Neogene stages. arenaceous benthic foraminifers Pavonitina. Radiolarians, diatoms, and siliceous nannoplankton clearly demonstrate a relationship between floras and faunas of the subtropical and temperate areas of the IndoPacific in contrast to those of the Mediterranean (Dumitrica et al., 1975; Rögl and Müller, 1976). This is supported by the distribution of calcareous nannoplankton; discoasters, generally common in the Mediterranean, are extremely rare or even missing in the Paratethys. In contrast, species such as Rhabdosphaera poculi and Nannocorbis challengeri are extremely abundant in samples from the Paratethys, but are very rare in the Mediterranean samples. They do occur, however, in the middle Miocene (NN 7) of the Indian Ocean. These facts lead us to conclude that an active connection between the Paratethys and the Mediterranean was closed (loc. 1) and that the Indo-Pacific oceanic strait was reactivated, following the early Badenian connections (s.a., loc. 2). One of the marine transgressions known from the Gulf of Oman (Buchbinder and Gvirtzman, 1976) must have spread further northwest through the Mesopotamian trough up to Anatolia (Gelati, 1975) and into the Paratethys area. This late Badenian marine phase ended the marine sequences within the Paratetbys.

\section{THE LATE MIOCENE FRESHENING}

According to Buchbinder and Gvirtzman (1976) the marine and evaporitic sedimentation in the Mesopotamian trough ended at about 12 m.y.B.P. The closure of the marine connection to the Paratethys resulted in a progressively more fresh Paratethyan Sea. The closure caused by plate movements a well-marked and farreaching early Sarmatian transgression. During the late Miocene and Pliocene, the freshening of this huge intracontinental Paratethyan Sea continued with a rapidly changing endemic faunal development. The breakdown of the intracontinental sea into small local basins (e.g., Pannonian, Dacian, Euxinian, and Caspian basins) which in turn evolved into the so-called Caspian brackish lakes, ended the existence of the Paratethys Sea.

\section{ACKNOWLEDGMENTS}

The authors wish to thank the Deep Sea Drilling Project for the opportunity to contribute to the Leg 42A Study of the Mediterranean Sea. We are also indebted to all our colleagues who helped with comments and discussions, especially G. Bizon, M. B. Cita, V. Kochansky-Devide, K. Hsü, and $\mathrm{R}$. Wright. Of great value was information provided by the members of the Paratethys working group of CMNS.

\section{Additional Remarks}

During the C.M.N.S. council meeting in Smolenice (ČSSR), February 1977, the discussion of paleogeographic relations between Paratethys and the Mediterranean brought about the following essential facts.

A direct marine connection between the Paratethys Sea and the Indo-Pacific Ocean was missing in Karpatian time. According to E. Kojumdgieva (Bulgaria) there is no marine sedimentation within the Lom Basin in this time (see Figure 4 , loc. 2). After G. Bizon (France) the marine connection to 
the south follows the Drava-Sava depression continuing throuth the Mesohelenic trough into the eastern Mediterranean. This seaway ceased after the Karpatian.

Özsayer (1977) showed that the Badenian in Turkey along the southern Black Sea coast is developed in the facies of eastern Paratethys, with brackish water "Spaniodon" beds. This demonstrates that the seaway to the Indo-Pacific was closed at the middle Badenian desiccation phase as postulated above. The reopening for a marine circulation with the Indo-Pacific as assumed above is verified by the facies development in northern Anatolia near Trabzon in the upper Badenian.

\section{REFERENCES}

Becker-Platen, J. D., 1971. Stratigraphic division of the Neogene and oldest Pleistocene in southwest Anatolia: Newsl. Stratigr., v. 1, p. 19-22.

Bering, D., 1971. Lithostratigraphie, tektonische Entwicklung und Seengeschichte der neogenen und quarären intramontanen Becken der Pisidischen Seenregion (Südanatolien): Beih. Geol. Jb., v. 101, p. 1-150.

Brinkmann, R., 1976. Geology of Turkey: Enke Verl., Stuttgart.

Buchbinder, B. and Gvirtzman, G., 1976. The breakup of the Tethys Ocean into the Mediterranean Sea, the Red Sea, and the Mesopotamian Basin during the Miocene: a sequence of fault movements and desiccation events: Abstr., 1st. Congr. Pacific Neog. Stratigr. Tokyo, p. 32-35.

Cicha, I., Fahlbusch, V., and Fejfar, O., 1972. Biostratigraphic correlation of some late Tertiary vertebrate faunas in Central Europe: N.Jb., Paläont. Abh., v. 140, p. 129145.

Cicha, I., Marinescu, F. and Senes, J., 1975. Correlation du éogène de la Paratethys Centrale: Geol. Surv., 33 p.

C tyrocky, P., Karim, S. A., and Vessem van, E. J., 1975. Miogypsina and Borelis in the Euphrates limestone formation in the western desert of Iraq: N.Jb. Geol. Paläont. Abh., v. 148, p. 33-49.

Daniels, C. H. v. and Ritzkowski, S., 1970. Marines Miozän Orbulina suturalis-Zone) in Istrien/Jugoslawien: ött. Arb. Geol. Paläont., v. 5, p. 31-36.

Dewey, J. F., Pittman, W. C., III, Ryan, W. B. F., and Bonnin, J., 1973. Plate tectonics and the evolution of the Alpine system: Geol. Soc. Am. Bull., v. 84, p. 3137-3180.

Dumitrica, P., Gheta, N., and Popescu, G. H., 1975. New data on the biostratigraphy and correlation of the middle Miocene in the Carpathian area: Dari Seama Sedint., v. 61, p. 65-84.

Gelati, R., 1975. Miocene marine sequence from the Lake Van area, eastern Turkey: Riv. Ital. Paleontol., v. 81, p. $477-490$

Herz, N. and Savu, H., 1974. Plate tectonics history of Romania: Geol. Soc. Am. Bull., V. 85, p. 1429-1440.
Hsü, K. I., 1971. Origin of the Alps and western Mediterranean: Nature, v. 233, p. 44-48.

Jiř iček, R., 1975. Biozonen der Zentralen Paratethys: NAFTA, Gbely (ČSSR).

Kokay, J., 1967. Stratigraphie des Oberhelvets ("Karpatien'”) von Várpalota (Ungarn): Paleontogr. Ital., v. 63, p. 75-111.

1973. Faziosratotypen der Bántapusztaer Schichtengruppe. In Papp, A., Rögl, F., and Senes,, J., $\mathrm{M}_{2}$ Ottnangien-Chronostrat. and Neostrat., v. 3, p. 227-243.

Lange, S. P., 1971. The subdivision of the Cenozoic in eastern Central Anatolia: Newsl. Stratigr., v. 1, p. 37-40.

Lüttig, G. and Steffens, P.,1976. Explanatory notes for the paleogeographic atlas of Turkey from the Oligocene to the Pleistocene: Paleogeogr. Atlas Turkey, p. 1-64.

McKenzie, D. P., 1970. Plate tectonics of the Mediterranean region: Nature, v. 226, p. 239-243.

Müller, C., 1974. Calcareous nannoplankton, Leg 25 (Western Indian Ocean). In Simpson, E. S. W., Schlick, R. et al., Initial Reports of the Deep Sea Drilling Project, Volume 25: Washington (U.S. Government Printing Office), p. 579-633.

Neev, D., 1975. Tectonic evolution of the Middle East and the Levantine basin (easternmost Mediterranean): Geology, v. 3, p. 683-686.

Nevesskaya, L. A., Bagdasarjañ, K. G., Nosovsky, M. F., and Paramonova, N. P., 1975a. Stratigraphic distribution of bivalvia in the Eastern Paratethys: Rept. Activ. R.C.M.N.S. Working Groups (1971-1975), p. 48-74.

Nevesskaya, L. A., Bogdanovich, A. K., Vialov, O. S., Shishtschenko, B. P., Ilina, L. B., and Nosovsky, M. F., 1975. Stufen-Skala neogener Schichten Südrusslands (östliche Paratethys): Proc. 6. Congr. R.C.M.N.S., v. 1, p. 267-289.

Özsayar, T. Y., 1977. A study on Neogene formations and their molluscan fauna along the Black Sea coast, Turkey: Black Sea Tech. Univ. Publ. no. 79, Fac. Earch sci. publ., v. 9, p. 1-80.

Papp, A., 1969. Die Koordinierung des Miozäns in der Paratethys: Verh. Geol. Bundeanst., v. 1, p. 2-6.

Rögl, F. and Müller, C., 1976. Das Mittelmiozän und die Baden-Sarmat-Grenze in Walbersdorf (Burgenland): Ann. Naturhist. Mus. Wien, v. 80, p. 221-232.

Seneş, J. et al. (Kollektiv), 1971. Korrelation des Miozäns der Zentralen Paratethys (Stand 1970): Geol. Zbornik, Geol. Carp., v. 22, p. 3-9.

Sickenberg, O., 1975. Die Gliederung des höheren Jungtertiärs und Altquartärs in der Türkei nach Vertebraten und ihre Bedeutung für die internationale Neogen-Stratigraphie: Geol. Jb., Reihe B., v. 15, p. 1-167.

Steininger, F., Rögl, F., and Martini, E., 1975. Current Oligocene/Miocene biostratigraphic concept of the Central Paratethys (Middle Europe). Newsl. Stratigr., v. 4, p. 174-202. 